\title{
Folinic Acid Enhanced Cytotoxicity of Fluoropyrimidines in Human Breast Cancer Cells*
}

\author{
Frederika Mandelbaum-Shavit \\ Department of Bacteriology, Hebrew University-Hadassah Medical School, Jerusalem, Israel
}

(Received January 30, 1993)

\begin{abstract}
Summary
This report describes the effects of the natural diastereoisomer of 5-formyltetrahydrofolate (6S)- and of the mixture of both the natural and unnatural diastereoisomers (6R,S)-5-HCO-H ${ }_{4} \mathrm{PteGlu}$ (folinate) on the cytotoxicity of 5-fluoro-2'-deoxyuridine (FdUrd) and 5-fluorouracil (FUra) in MCF-7 and MDA-MB 231. human breast cancer cell lines. Continuous exposure of exponentially growing cells to various concentrations of FUra for $72 \mathrm{~h}$ caused a $50 \%$ inhibition of growth with $\mathrm{IC}_{50}$ at concentrations of $3.40 \pm 0.16$ and $29 \pm 1.40$ $\mu \mathrm{M}$ in MCF-7 and MDA-MB 231, respectively. Preincubation of the cells for $24 \mathrm{~h}$ with $(6 \mathrm{~S})-5-\mathrm{CHO}-\mathrm{H}_{4} \mathrm{Pte}-$ Glu $(5 \mu \mathrm{M})$ prior to addition of FUra decreased the $\mathrm{IC}_{50}$ values by $2.4-2.6$-fold in both cell lines. A quantitatively similar effect was achieved by preincubation with $10 \mu \mathrm{M}$ of $(6 \mathrm{R}, \mathrm{S})-5-\mathrm{HCO}-\mathrm{H}_{4} \mathrm{PteGlu}$. The cytotoxicity of FdUrd was markedly more pronounced than that of FUra exhibiting IC $_{50}$ values at a range of 0.045 $0.050 \mu \mathrm{M}$ for both cell lines. Preincubation with $(6 \mathrm{~S})-5-\mathrm{HCO}-\mathrm{H}_{4}$ PteGlu increased the susceptibility to the drug by about 3,5-fold. The optimal dose of $(6 \mathrm{~S})-5-\mathrm{CHO}-\mathrm{H}_{4} \mathrm{PteGlu}$ for achieving the lowest $\mathrm{IC}_{50}$ value for FdUrd in MCF-7 cells was $5 \mu \mathrm{M}$. whereas that in MDA-MB 231 was $20 \mu \mathrm{M}$. Similar increase of the cytotoxicity of FdUrd was obtained with about a 2-fold higher concentration of (6R.S)-5-HCO-H $\mathrm{H}_{4} \mathrm{PteGlu}$.

Cells pretreated for $24 \mathrm{~h}$ with FUra or FdUrd respectively, exhibited enhanced incorporation of ['H] thymidine into the TCA-precipitable fraction. Presence of $(6 \mathrm{~S})-5-\mathrm{HCO}-\mathrm{H}_{4} \mathrm{PteGlu}(10 \mu \mathrm{M})$ doubled the amount of incorporated thymidine, which reflects depletion of intracellular thymidylate pools due to enhanced formation and stabilization of the complex formed between thymidylate synthase, fluorodeoxyuridylate and 5.10-methylenetetrahydrofolate.
\end{abstract}

Key words: Folinic acid. Cytotoxicity, Fluoropyrimidines. Human breast cancer cell lines

\section{Introduction}

Fluoropyrimidines, mainly 5-fluorouracil (FUra) and 5-fluoro-2'-deoxyuridine (FdUrd) are important chemotherapeutic drugs used extensively in the treatment of carcinomas of the gastrointestinal tract. breast, ovary and other tumors. Studies in vitro have shown a marked potentiation of the cytotoxicity of FdUrd in mouse leukemia L1210 cells by 5-formyltetrahydrofolate $\left(5-\mathrm{HCO}-\mathrm{H}_{4} \mathrm{PtcGlu}\right)(1)$, known as folinate or leucovorin. a mixture of the natural $(6 \mathrm{~S})$ and unnatural (6R)-diastereoisomers. The folinate-

\footnotetext{
*This article was presented at the Sixth International Conference on Pteridines and Related Biogenic Amines and Folates, held June 1992 in Seoul Korea.
}

Pteridines / Vol. 4 / No. 1 enhanced cytotoxicity of FUra or FdUrd was observed later in mouse $\mathrm{S}-180$ sarcoma and human Hep-2 carcinoma (2), in Friend erythroleukemia (3), murine and human leukemia cells $(4,5)$, human colorectal (6). squamous cell carcinoma (7) and recently in several human lung cancer cell lines (8). Thus, folinate acts as a modulator of the cytotoxicity of fluoropyrimidines and has been exploited as such to increase the clinical effectiveness of these drugs (9).

The cytotoxicity of fluoropyrimidines is based upon the following main mechanisms of action: inhibition of thymidylate synthase (TS) by 5-fluoro$2^{\prime}$-deoxyuridine- $5^{\prime}$-monophosphate (FdUMP), anabolized from FdUrd or FUra (10), incorporation of 
enhanced cytotoxicity of FUra or FdUrd was observed later in mouse S-180 sarcoma and human Hep-2 carcinoma (2), in Friend erythroleukemia (3), murine and human leukemia cells $(4,5)$, human colorectal (6), squamous cell carcinoma (7) and recently in several human lung cancer cell lines (8). Thus, folinate acts as a modulator of the cytotoxicity of fluoropyrimidines and has been exploited as such to increase the clinical effectiveness of these drugs (9).

The cytotoxicity of fluoropyrimidines is based upon the following main mechanisms of action: inhibition of thymidylate synthase (TS) by 5-fluoro$2^{\prime}$-deoxyuridine-5'-monophosphate (FdUMP), anabolized from FdUrd or FUra (10), incorporation of FUra into RNA (11) and incorporation of fluorodeoxyuridine triphosphate into DNA (12). Inhibition of de novo synthesis of thymidylate due to formation of a covalent ternary complex involving FdUMP. TS and 5,10 methylenetetrahydrofolate $\left(5,10-\mathrm{CH}_{2}-\mathrm{H}_{4}\right.$ PteGlu) causes depletion of the thymidylate pool and finally inhibition of the synthesis of DNA. Presence of a reduced folate, which can be anabolized into $5,10-\mathrm{CH}_{2}-\mathrm{H}_{4} \mathrm{PteGlu}$ is critical for stabilization of the ternary complex $(13.14)$ and thus inhibition of the synthesis of thymidylate.

The purpose of the present study was to examine the effects of folinate, (racemic 6R.S)-, and of the natural (6S)-isomer on the cytotoxicity of FUra and FdUrd in MCF-7 and MDA-MB 231. human breast cancer cell lines exposed to a continuous drug treatment. To further elucidate the effect of these fluorinated pyrimidines with and without $5-\mathrm{HCO}-\mathrm{H}_{4} \mathrm{Pte}-$ Glu on the cellular pool of thymidylate, we followed the incorporation of $\left[{ }^{3} \mathbf{H}\right]$ thymidine into the cold TCA-precipitable fraction of cells pretreated with various combinations of the mentioned drugs.

\section{Materials and Methods}

\section{Chemicals}

Folinic acid (calcium salt), FUra. FdUrd and MTT (3-[4,5-dimethylthiazol-2-yl]-2,5-diphenyltetrazolium bromide) were purchased from Sigma Chemical Co., St Louis, MO. (6S)-HCO-H4 $\mathrm{H}_{4}$ teGlu was a product of Sapec S.A. Barbengo. Switzerland. $\left[6{ }^{3} \mathrm{H}\right]$ Thymidine, specific activity $22 \mathrm{Ci} / \mathrm{m}$ mol was purchased from Amersham International, Buckinghamshire. England.

Cell culture
The cell lines MCF-7 and MDA-MB 231 were cultivated in RPMI 1640 medium obtained from Biological Industries, Bet Haemek, supplemented with $10 \%$ dialyzed fetal bovine serum, $2 \mathrm{mM} \mathrm{L-glu-}$ tamine, penicillin (100 units/ml) and streptomycin $(100 \mu \mathrm{g} / \mathrm{ml})$. For growth inhibition studies, exponentially growing cells were dispersed into 24-well plates and incubated in a humidified incubator at $37^{\circ} \mathrm{C}$. under an atmosphere of $5 \% \mathrm{CO}_{2}$ for 24 or $48 \mathrm{~h}$ for MDA-MB 231 and MCF-7 cells respectively. The exponentially growing cells were then incubated with or without $(6 \mathrm{~S})-5-\mathrm{HCO}-\mathrm{H}_{4}$ PteGlu for $24 \mathrm{~h}$. Subsequently, drugs were added and the cultures were reincubated for an additional $72 \mathrm{~h}$. The growth was terminated by two washes with phosphate buffered saline (PBS) and to obtain a single-cell suspension. the monolayers were incubated at $37^{\circ} \mathrm{C}$ for $10 \mathrm{~min}$ with $0.1 \%$ EDTA in PBS without calcium and magnesium. The cells were quantitated by counting in a hemocytometer.

\section{MTT colorimetric assay}

Cell survival was assessed by an assay (15), based on the reduction of the MTT to a water-insoluble formazan in mitochondria of living cells. $10 \mu \mathrm{l}$ of MTT at a concentration of $5 \mathrm{mg} / \mathrm{ml}$ in PBS were added into each well containing $100 \mu \mathrm{l}$ medium and the cell monolayer and the plates were incubated for $4 \mathrm{~h}$ in a humidified incubator at $37^{\circ} \mathrm{C}$ in a $5 \%$ $\mathrm{CO}_{2}$ atmosphere. Subsequently the medium was removed. the formazan crystals produced by the viable

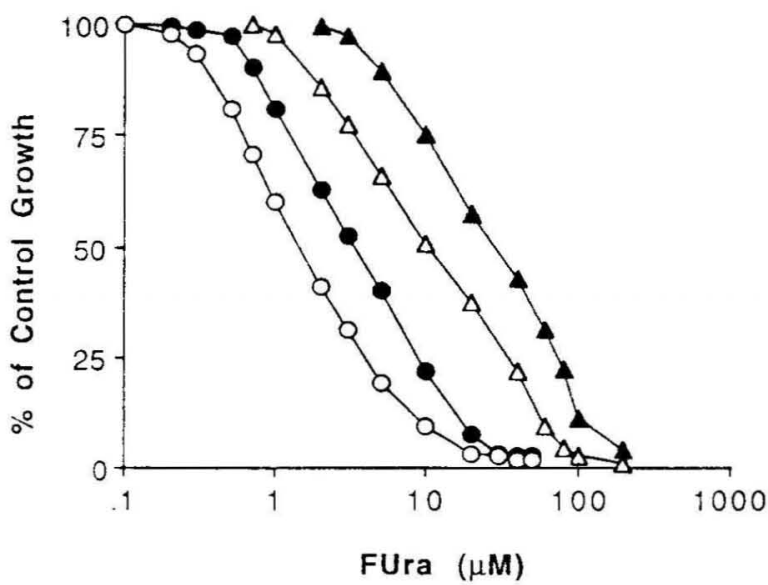

Figure 1. Fffect of FUra and $(6 \mathrm{~S})-5-\mathrm{HCO}-\mathrm{H}_{4} \mathrm{Pte}$ (ilu on growth of $\mathrm{MCF}-7$ and MDA-MB 231 cells. Experimental conditions were as described in Materials and Methods. MCF-7 cells without (-) and with (f) 5-HCO-H 4 PteGlu; MDA-MB 231 cells without (A) and with () 5-HCO-H4Pteclu. Points represent the mean value of three experiments in triplicate and the S.E. are within the symbols. 


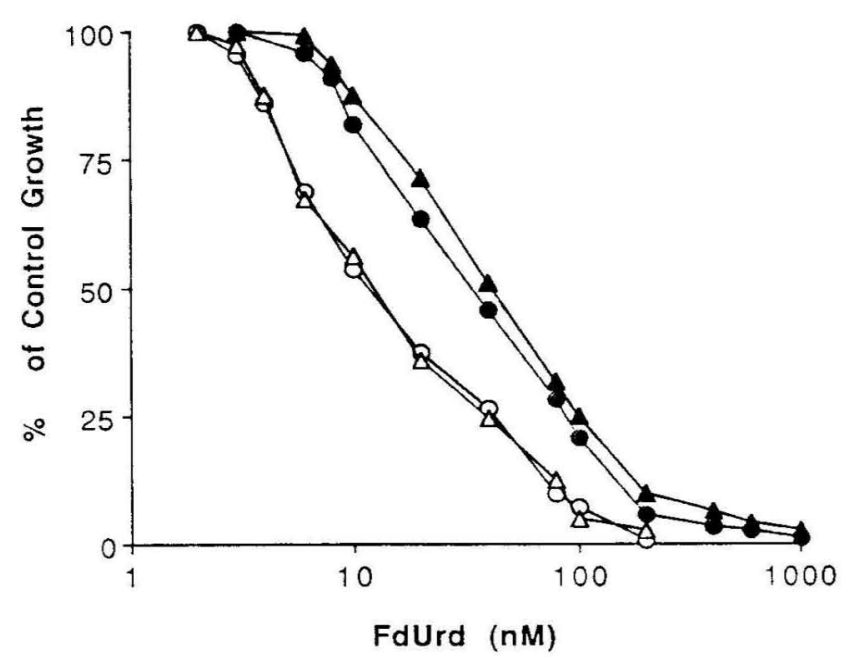

Figure 2. Effect of FdUrd and (6S)-5-HCO-H $\mathrm{H}_{4} \mathrm{PteGlu}$ on growth of MCF-7 and MDA-MB 231 cells. Experimental conditions and symbols were as in Fig. 1. Points represent the mean value of three experiments in triplicate with S.E. within the symbols.

Table 1. Effect of increasing concentrations of (6S)- and (6R,S)-5-HCO-H $\mathrm{H}_{4}$ PteGlu on the cytotoxicity of FdUrd in MCF-7 and MDA-MB 231 cell lines.

\begin{tabular}{ccc}
\hline \multicolumn{3}{c}{ FdUrd $I_{s 0}(\mathrm{nM})$} \\
MCF-7 & MDA-MB 231 \\
\hline$(6 \mathrm{~S})-5$-HCO-H ${ }_{4}$ PteGlu & $(\mu \mathrm{M})$ & \\
- & $45.1 \pm 5.2$ & $49.3 \pm 7.1$ \\
0.1 & $43.3 \pm 6.0$ & $47.8=6.3$ \\
0.5 & $23.4 \pm 3.3$ & $42.1 \pm 6.0$ \\
2.0 & $15.6 \pm 2.3$ & $21.3 \pm 3.2$ \\
5.0 & $12.3 \pm 1.6$ & $13.6 \pm 2.0$ \\
10.0 & $12.5 \pm 1.4$ & $11.5 \pm 1.3$ \\
20.0 & $12.4 \pm 1.3$ & $9.2 \pm 1.1$ \\
$(6 \mathrm{R} . \mathrm{S})-5-\mathrm{HCO}-\mathrm{H}_{4}$ PteGlu & $(\mu \mathrm{M})$ & \\
5.0 & $15.1 \pm 2.0$ & $22.4 \pm 3.3$ \\
10.0 & $12.5 \pm 1.8$ & $13.9 \pm 1.9$ \\
20.0 & $12.4 \pm 1.5$ & $10.9 \pm 1.3$ \\
50.0 & $12.5 \pm 1.4$ & $8.9 \pm 1.1$
\end{tabular}

Cells $\left(3 \times 10^{3}\right)$ were plated into 96 -well plates and incubated for $24 \mathrm{~h}$ in RPM 11640 medium supplemented with $10 \%$ dialyzed fetal bovine serum and the indicated concentrations of (6S)-or (6R.S)-5-HCO-H $\mathrm{H}_{4}$ PteGlu. Subsequently various concentrations of FdUrd were added and the cultures were reincubated for $48 \mathrm{~h}$ with MDA-MB 231 and for $72 \mathrm{~h}$ with MCF7 cells. Cell growth was measured by a MTT colorimetric assay. Values are means \pm S.E. of three experiments in triplicate.

cells were solubilized in $150 \mu \mathrm{l}$ of dimethyl sulfoxide and the optical density was read at $550 \mathrm{~nm}$ in a scanning multiwell spectrophotometer (SLTLabinstruments, Austria).
Table 2. Effect of increasing concentrations of (6S)-and (6R,S)-5-HCO-H $\mathrm{H}_{4}$ PteGlu on the cytotoxicity of FUra in MCF-7 and MDA-MB 231 cell lines.

\begin{tabular}{ccc}
\hline \multicolumn{3}{c}{ FUrd $\mathrm{IC}_{50}(\mu \mathrm{M})$} \\
MCF-7 & MDA-MB 231 \\
\hline$(6 \mathrm{~S})-5$-HCO-H ${ }_{4}$ PteGlu & $(\mu \mathrm{M})$ & \\
- & $3.46 \pm 0.28$ & $31.21 \pm 2.83$ \\
0.1 & $2.97 \pm 0.24$ & $28.53 \pm 2.55$ \\
1.0 & $2.01 \pm 0.19$ & $16.57 \pm 1.81$ \\
5.0 & $1.51 \pm 0.13$ & $11.21 \pm 1.30$ \\
10.0 & $1.40 \pm 0.12$ & $10.03 \pm 1.23$ \\
20.0 & $1.52 \pm 0.14$ & $9.10 \pm 1.02$ \\
$(6 \mathrm{R}, \mathrm{S})-5-\mathrm{HCO}-\mathrm{H}_{4}$ PteGlu & $(\mu \mathrm{M})$ & \\
1.0 & $2.53 \pm 0.19$ & $24.03 \pm 2.11$ \\
5.0 & $1.91 \pm 0.15$ & $18.11 \pm 1.75$ \\
10.0 & $1.54 \pm 0.12$ & $11.95 \pm 1.20$ \\
\hline
\end{tabular}

Experimental details are as in Table 1. Values are means $\pm \mathrm{S}$. E. of three experiments in triplicate.

\section{Incorporation of $\left[{ }^{3} \mathrm{H}\right]$ thymidine}

The drug-exposed cells were washed twice with $1 \mathrm{ml}$ PBS; $\left[{ }^{3} \mathrm{H}\right]$ thymidine was added in $1 \mathrm{ml}$ of serum-free medium and after incubation for $1 \mathrm{~h}$ at $37^{\circ} \mathrm{C}$ in a humidified incubator, the cells were washed three times with $2 \mathrm{ml}$ of ice-cold PBS and the radioactivity was determined in cold 5\% trichloroacetic acid-precipitate solubilized in $1 \mathrm{~N} \mathrm{NaOH}$. Samples, neutralized with $\mathrm{HCl}$ were counted in a Triton-toluene scintillation fluid.

\section{Results}

Inhibition of growth of MCF-7 and MDA-MB 231 cells by FUra and FdUrd in the presence and absence of (6S)-5-HCO-H${ }_{4}$ PteGlu.

Exposure of the cells to increasing concentrations of FUra caused inhibition of growth with $\mathrm{IC}_{51}$ values of $3.4 \pm 0.16$ and $29 \pm 1.8 \mu \mathrm{M}$ for MCF-7 and MDAMB 231. respectively (Fig. 1). Preincubation for 24 $\mathrm{h}$ with $5 \mu \mathrm{M}(6 \mathrm{~S})-5-\mathrm{HCO}-\mathrm{H}_{4} \mathrm{PteGlu}$ prior to addition of the drug caused a 2.4-2.6-fold decrease of the $\mathrm{IC}_{50}$ values in both cell lines. $5-\mathrm{HCO}-\mathrm{H}_{4} \mathrm{PteGlu}$ by itself did not affect growth.

The susceptibility of both cell lines to FdUrd is markedly higher than to FUra, exhibiting almost the same $\mathrm{IC}_{50}$ values, namely $45 \pm 2.8$ and $49 \pm 3.9$ $\mathrm{nM}$ for MCF-7 and MDA-MB 231 respectively. The effect of the reduced folate was more pronounced than with FUra and caused an about 3.5-fold increase in cytotoxicity (Fig. 2). 
Table 3. Incorporation of $\left[{ }^{3} \mathrm{H}\right]$ thymidine into DNA of MCF-7 and MDA-MB 231 cells pretreated with FUra and FdUrd in the presence and absence of $(6 \mathrm{~S})-5-\mathrm{HCO}-\mathrm{H}_{4} \mathrm{PteGlu}$.

\begin{tabular}{|c|c|c|}
\hline & \multicolumn{2}{|c|}{$\left[{ }^{3} \mathrm{H}\right]$ Thymidine Incorporated $(\%)$} \\
\hline & $\mathrm{MCF}-7$ & MDA-MB 231 \\
\hline Control & $100.0 \pm 5.2$ & $100.0 \pm 5.8$ \\
\hline$(6 \mathrm{~S})-5-\mathrm{HCO}-\mathrm{H}_{4} \mathrm{PteGlu}$ & $100.0 \pm 5.4$ & $100.0 \pm 3.5$ \\
\hline FUra $(5 \mu \mathrm{M})$ & $147.2 \pm 9.2$ & $128.9 \pm 8.3$ \\
\hline FUra $(5 \mu \mathrm{M})+(6 \mathrm{~S})-5-\mathrm{HCO}-\mathrm{H}_{4}$ PteGlu & $242.6 \pm 12.4$ & $226.6 \pm 15.3$ \\
\hline FUra $(10 \mu \mathrm{M})$ & $196.9 \pm 13.6$ & $151.3 \pm 10.2$ \\
\hline FUra $(10 \mu \mathrm{M})+(6 \mathrm{~S})-5-\mathrm{HCO}-\mathrm{H}_{4}$ PteGlu & $245.4 \pm 15.1$ & $231.2 \pm 14.8$ \\
\hline FdUrd $(0.02 \mu \mathrm{M})$ & $115.1 \pm 8.1$ & $118.1 \pm 9.7$ \\
\hline FdUrd $(0.02 \mu \mathrm{M})+(6 \mathrm{~S})-5-\mathrm{HCO}-\mathrm{H}_{4}$ PteGlu & $250.5 \pm 20.2$ & $195.6 \pm 19.3$ \\
\hline FdUrd $(0.05 \mu \mathrm{M})$ & $186.9 \pm 14.0$ & $205.4 \pm 12.6$ \\
\hline FdUrd $(0.05 \mu \mathrm{M})+(6 \mathrm{~S})-5-\mathrm{HCO}-\mathrm{H}_{4}$ PteGlu & $266.9 \pm 24.1$ & $265.1 \pm 13.9$ \\
\hline
\end{tabular}

Drugs were added into exponentially growing cells at almost confluency in 24-ucll plater and the cultures were incubated for $24 \mathrm{~h}$. The concentration of $(6 \mathrm{~S})-5-\mathrm{HCO}-\mathrm{H}_{4} \mathrm{PteGlu}$ added was $10 \mu \mathrm{M}$. The drug treatment was terminated by two washes with PBS. $\left[{ }^{3} \mathrm{H}\right]$ thymidine $(60 \mathrm{pmol} / 0.4 \mu \mathrm{Ci})$ was added in $1 \mathrm{ml}$ of serum free medium and the cells were incubated for $1 \mathrm{~h}$ at $37^{\circ} \mathrm{C}$. Further details are as described in Materials and Methods. Values are mean \pm S.E. of three experiments in triplicate.

Effect of increasing concentrations of (6S) and (6R.S)5-HCO-H$H_{4}$ PteGlu on the crtotoxicity of FdUrd and FUra in MCF-7 and MD.4-1AB 231 c'ell lines.

As depicted in Table 1. exposure of the cell for $24 \mathrm{~h}$ to increasing concentrations of the natur.d iwmer of 5-HCO-H4PteGlu or to folinate caused increasing cytotoxicity of FdUrd. The maximal enhancement of MCF-7 and MDA-MB cell kill was at 5 and $20 \mu \mathrm{M}$ respectively. Since the cytotoxicity achieved at $5 \mu \mathrm{M}$ of the $(6 \mathrm{~S})$-isomer corresponds to that at $10 \mu \mathrm{M}$ of $(6 \mathrm{R}, \mathrm{S})-5-\mathrm{HCO}-\mathrm{H}_{4}$ PteGlu, it could be assumed that the unnatural isomer does not contribute to enhancement of cytotoxicity. MDA cells incubated with $100 \mu \mathrm{M}$ folinate did not exhibit further enhancement of the cytotoxicity of FdUrd (not shown).

Table 2 depicts a similar experiment performed with FUra. With this drug, as well, the most effective concentration of the $(6 \mathrm{~S})$-isomer appears to be at $5 \mu \mathrm{M}$ for $\mathrm{MCF}-7$ cells which corresponds to the effect obtained with $10 \mu \mathrm{M}$ of $(6 \mathrm{R}, \mathrm{S})-5-\mathrm{HCO}-\mathrm{H}_{4}$ PteGlu. The maximal enhancement of the cytotoxicity of FUra for MDA-MB 231 cells was at $20 \mu \mathrm{M}$ of the $(6 \mathrm{~S})-5-\mathrm{HCO}-\mathrm{H}_{4}$ PteGlu.

Incorporation of $\left[{ }^{3} \mathrm{H}\right]$ thymidine into DNA of $\mathrm{MCF}-7$ and MDA-MB 231 cells treated with fluoropyrimidines in the presence and absence of (6S)-5-HCO-H PteGlu.

To determine the relation betucen enhancement of the cytotoxicity of fluoropyrimidines by folinate and depletion of the intracellular thymidylate pool. we examined the incorporation of $\left[{ }^{3} \mathrm{H}^{\top}\right.$ thymidine into cells pretreated with various combinations of the above drugs. As shown in Table 3, exposure to FUra at a concentration of $5 \mu \mathrm{M}$ increased the incorporated radioactivity by $47.2 \%$ in $\mathrm{MCF}-7$ and by $28.9 \%$ in MDA-MB 231 cells, which correlates with the lower susceptibility of the latter to FUra. Cells treated with 11) UM FUra exhibited an increased incorporation of thymidine and at both drug concentrations. the inosporation was enhanced by $(6 \mathrm{~S})-5-\mathrm{HCO}-\mathrm{H}_{4} \mathrm{Pte}-$ Glu.

Treatment with Fdl rd at a 250 times lower concentration than that of FUra markedly enhanced the incorporation of thymidine. which was also augmented by the presence $(6 \mathrm{~S})-5-\mathrm{HCO}-\mathrm{H}_{4}$ PteGlu.

\section{Discussion}

We have shown that (6S)-5- $\mathrm{HCO}-\mathrm{H}_{4} \mathrm{PteGlu}$ enhanced the cytotoxicity of FdUrd and FUra in MCF7 and MDA-MB 231, human breast cancer cell lines (Figs. 1, 2), which is in agreement with the data obtained in studies with other tumor cell lines (1-8). Folinate, a mixture of the natural and unnatural isomers, exhibited a $50 \%$ activity of that of the natural isomer (Tables 1.2). Thus, the (6R) isomer does not act as a modulator of the cytotoxicity of fluoropyrimidines. and does not interfere with the enhancing activity of the natural isomer, as also recently shown in an ileocecal carcinoma cell line (16). Although the (6R)-isomer is not biologically inert and inhihits competitively the uptake of the $(6 \mathrm{~S})$-compound in human lymphoblastic leukemia CCRFCEM cells, the apparent $\mathrm{Ki}$ value is relatively high and the cellular accumulation markedly lower than 
that of the natural isomer (17).

The susceptibility of both cell lines to FdUrd is markedly higher than to FUra and so is the enhancement of the cytotoxicity by the reduced folate (Figs. 1, 2). Similar phenomenon was found in mouse and human leukemia cells (4.5). and in several human lung cancer cell lines (8). This difference in cytotoxicity, as well as in the enhancing effect of folinate, may be explained. at least partially by a more efficient anabolism of FdUrd into FdUMP. a potent inhibitor of TS. FdUMP binds to the enzyme and $5,10-\mathrm{CH}_{2}-\mathrm{H}_{4} \mathrm{PteGlu}$ forming a ternary complex, which is also stabilized by this reduced folate $(13,14)$. Formation of the stable ternary complex results in inhibition of thymidylate synthesis and thus presumably, depletion of its intracellular pool. The data depicted in Table 3. support this hypothesis by showing that exposure of MCF-7 and MDA-MB 231 cells to the fluorinated pyrimidines results in increased incorporation of $\left[{ }^{3} \mathrm{H}\right]$-thymidine, which is also markedly augmented by the presence of $(6 \mathrm{~S})$ 5-HCO- $\mathrm{H}_{4}$ PteGlu.

The results of this study indicate that MCF-7 and MDA-MB 231 cells are able to metabolize the 5-HCO- $\mathrm{H}_{4} \mathrm{PteGlu}$ into $5,10-\mathrm{CH}_{2}-\mathrm{H}_{4} \mathrm{PteGlu}$ and the fluorinated pyrimidines into FdUMP, which are crucial components of the ternary complex with TS. The recently published paper by Boarman et al. strengthens this assumption by demonstrating that increasing concentrations of $5-\mathrm{HCO}-\mathrm{H}_{4} \mathrm{PteGlu}$ in the growth medium of MCF-7 cells. increased the intracellular 5,10- $\mathrm{CH}_{2}-\mathrm{H}_{4}$ PteGlu pool (18).

Another important factor in the modulation of the cytotoxicity of fluoropyrimidines by folinate appears to be the availability of the polyglutamates of the 5,10- $\mathrm{CH}_{2}-\mathrm{H}_{4}$ PteGlu. As recently shown, the growth inhibitory effect of fluoropyrimidines on CCRF-CEM cells increased in the presence of folinate, but no such effect could be found in a subline of these cells with an impaired ability to form poly- glutamates (19).

The results of the presented study suggest that a prolonged exposure to folinate, prior to that of fluoropyrimidines will supply a pool of $5,10-\mathrm{CH}_{2}-\mathrm{H}_{4}$ PteGm and its polyglutamates reguired for a rapid formation of the ternary complex with TS, leading to inhibition of DNA synthesis and thus achieving optimal therapeutic effects.

\section{References}

1. Ullman B, Lee M, Martin DW, Jr, Santi DV. Proc Natl Acad Sci, USA 1978; 75: 980-983.

2. Evans RM, Laskin JD. Hakala MT. Cencer Res 1981; 41 : 3288-3295.

3. Waxman S, Bruckner H. Eur J Cancer Clin Oncol 1982; 18: 685-692.

4. Keyomarsi K. Moran RG. Cancer Res 1986; 46: 5229-5235.

5. Mini E. Moroson BA, Bertino JR. Cancer Treat Rep 1987: 71: $381-389$.

6. Park JG, Collins JM, Gazdar AF, Allegra CJ, Steinberg SM, Greene RF, Kramer BS. J Natl Cancer Inst 1988: 80: $1560-1564$.

7. Chang Y-M. and Bertino JR. Cancer Invest 1989; 7: 557563.

8. Tsai C-M. Gazdar AF. Allegra C. Perng RP. Kramer BS Int J Cancer 1990: 46: 101-105.

9. Arbuck SG. Cancer 1989; 63: 1036-1044.

10. Reyes P. Heidelberger C Mol Pharmacol 1965; 1: 14-30.

11. Glazer RI, Peale AL. Mol Pharmacol 1979; 16: 270-277.

12. Kufe DW, Major PP, Egan EM, Loh E. J Biol Chem 1981; 256: 8885-8888.

13. Santi DV. McHenry CS and Sommer H. Biochemistry 1974: 13: 471-480

14. Danenterg PV. Langenbach RJ. Heidelberger C. Biochemistry 1974: 13: 926-933.

15. Mosmann T. J Immunol Meth 1983; 65: 55-63.

16. Zhang Z-G. Rustum M. Cancer Res 1991; 51: 3476-3481.

17. Bertrand R. Jolivet J. J Natl Cancer Inst 1989: 81: 1175 1178.

18. Boarman DM, Allegra CJ. Cancer Res 1992; 52: 36-44.

19. Romanini A. Lin JT, Niedzwiecki D, Bunni M, Priest DG, Bertino JR. Cancer Res 1991; 51: 789-793. 